\title{
Eco-Interlocking Paving Block (Eco-IPB) by using LDPE/Sand Blends
}

\author{
Muhammad Halim Bachok ${ }^{1}$, Tuan Noor Hasanah Tuan Ismail ${ }^{1,2 *}$, Nur Faezah \\ Yahya $^{1,2}$, Mohd Hafizal Hanipah ${ }^{1,2}$, Muhamad Khairul Fitri Sarimin ${ }^{1}$, As'shar \\ Kasalan $^{1}$
}

${ }^{1}$ Department of Civil Engineering Technology, Faculty of Engineering Technology, Universiti Tun Hussein Onn Malaysia, 86400 Parit Raja, Batu Pahat, Johor, MALAYSIA

${ }^{2}$ Building Intelligent Management, Advanced Technology Centre,

Universiti Tun Hussein Onn Malaysia, 86400 Parit Raja, Batu Pahat, Johor, MALAYSIA

*Corresponding Author

DOI: https://doi.org/10.30880/ijie.2020.01.02.004

Received 18 July 2020; Accepted 11 October 2020; Available online 15 December 2020

\begin{abstract}
Bitumen and interlocking paving blocks are the common materials used in the construction of flexible road pavements in Malaysia and other developing countries. In the last few years, more focus has been paid on the interlocking paving block when dealing with less durable area because of certain environmental and organizational limitations. Nonetheless, cement has been used as a bonding agent in the conventional concrete interlocking paving block (CIPB) and has a detrimental effect on the environment. This research was therefore conducted to examine the alternative material to paving block by substituting cement content with plastic wastes; so called as an Ecointerlocking paving block (Eco-IPB). The aim of this research was to produce a sustainable, lightweight, stiff and cost-effective product. In this research, the Eco-IPB was prepared in four different LDPE/sand blends of 1:1, 1:2, 1:3 and 1:4. The thermal analysis and physical tests were conducted to determine the temperature effect and physical performance of plastic bags. The performance of Eco-IPB was evaluated with regard to the density measurement, water absorption and compression test. The findings showed that the optimum LDPE/sand ratio of Eco-IPB of LDPE was 1:2 based on the high compressive strength of $20.80 \mathrm{MPa}$ which had been achieved. Moreover, the widespread use of plastic waste as an alternative construction material will help to reduce plastic residues and promote green technology.
\end{abstract}

Keywords: Interlocking paving block, plastic bag (LDPE), Eco-Interlocking Paving Block, compressive strength

\section{Introduction}

A road pavement structure consists of multiple layers of refined and compacted materials, in different thicknesses and in both unpaved and paved roads, which together form a structure that primarily supports vehicle loads and offers a smooth riding consistency. The paved road pavements can be divided into two, flexible pavements and rigid pavements depending on the structural performance. However, the constructions of flexible pavement are layered on the surface with the bitumen and the interlocking blocks. The interlocking paving block was introduced a decade ago in Malaysia and many other countries. The main benefit of interlocking blocks over other substances is that they can later be lifted and replaced by individual bricks. It makes it possible to carry out remedial work under the paving floor without leaving a permanent mark as soon as the paving bricks are replaced.

Interlocking paving block (IPB) typically makes use for outside versatility utility and additionally used in a sidewalk, parking area, floor path of pavement (as pavement block) and other construction applications. It is divided by 
different grades as summarized in Table 1. However, Kasim and Rohim [1] recommended that the appropriate IPB strength for landscape is $20 \mathrm{MPa}$. Patel and Singh [2] stated that it usually used as problem-solving approaches for existing pavement in less stable areas due to the operational, floor and environmental constraints. Furthermore, these technologies have numerous advantages, along with speedy installation, convenient to handle, exquisite drainage capacity, limit construction time and speedy production. Interlocking paving block is solid, versatile, aesthetically attractive, functional, and cost-effective. The interlocking concrete paving blocks (ICPB) were first developed in the Netherlands in 1924 [3] replacing paver bricks that were scarce due to the post-war construction boom. ICPB differs from traditional flexible pavements mainly in its characteristics of superior load distribution and high strength abrasion resistant surface [4]. Typical concrete paving blocks have a clean face and a rough face, although some paving blocks can be used on both sides with interchangeable surfaces. However, the use of cement as a bonding agent in the ICPB production has led to global warming by the release of greenhouse gasses [1]. Furthermore, dust, nitrogen oxides (NOx), $\mathrm{CO} 2$ carbon dioxide and sulfur dioxide (SO2) are the most significant emissions caused by cement plants which have to be dealt with [5]. Besides, alkaline compounds such as lime (calcium oxide) are corrosive to human tissue due to the content of cement. [6]. In addition, small quantities of crystalline silica in concrete that is abrasive to the skin and can damage the lung [1], as well as causing environmental pollution.

Table 1 - Recommended IPB for different categories of traffic [7]

\begin{tabular}{|c|c|c|c|c|c|}
\hline $\begin{array}{l}\text { Sr. } \\
\text { no }\end{array}$ & $\begin{array}{l}\text { Grade. } \\
\text { Designation of } \\
\text { Paver Blocks }\end{array}$ & $\begin{array}{l}28 \text { Days } \mathbf{N} / \mathbf{m m} \\
\text { Compressive } \\
\text { strength }\end{array}$ & Category & $\begin{array}{l}\text { Recommended } \\
\text { thickness } \\
\text { minimum mm }\end{array}$ & Application \\
\hline 1 & M-25- M-30 & $25-30$ & $\begin{array}{l}\text { Non- } \\
\text { traffic }\end{array}$ & 50 & $\begin{array}{l}\text { Building premises parks, public } \\
\text { garden areas, household construct }\end{array}$ \\
\hline 2 & M-30-M-35 & $30-35$ & $\begin{array}{l}\text { Light- } \\
\text { traffic }\end{array}$ & 60 & $\begin{array}{l}\text { City streets, small and medium-sized } \\
\text { business roads, low-volume roads, } \\
\text { shutdowns on roads }\end{array}$ \\
\hline 3 & M-35-M45 & $35-45$ & $\begin{array}{l}\text { Medium- } \\
\text { traffic }\end{array}$ & 60,80 & $\begin{array}{l}\text { Bus terminals, industrial complexes, } \\
\text { mandi buildings, roads, factory } \\
\text { floors, service stations, retail floors }\end{array}$ \\
\hline 4 & M-45- M-55 & $45-55$ & $\begin{array}{l}\text { Heavy to } \\
\text { very } \\
\text { heavy }\end{array}$ & $80,100,120$ & $\begin{array}{l}\text { Export terminals, ports, warehouses, } \\
\text { access roads for mining, handling } \\
\text { areas for bulk cargo, pavements for } \\
\text { airports }\end{array}$ \\
\hline
\end{tabular}

According to SWCorp [8], the other most critical problems are related to plastic wastes. Plastic is one of the hazardous materials as it develops every day, since plastic waste is highly decomposed material [9]. Plastic is found to be very useful at the time of need. However, it is thrown away after used, increasing all kinds of risks to the environment. Plastic waste is a serious and longstanding problem due to its non-biodegradability in the natural environment even after a long period of time [9]. It is composed of major toxic pollutants, and has the potential to cause great harm to the environment in the form of air, water and land pollution. According to Ten [10], Malaysia is the eighth largest plastic waste country in the world. Malaysia is estimated to have created nearly one million tons of mismanaged plastic waste in 2010, but it may have been washed into the oceans from 0.14 to 0.37 million tons [11]. It will rise from year to year without any reduction and proper management.

Through reusing and recycling of plastic waste to a new green technical know-how specifically for civil engineering applications, it eliminates the environmental impact due to its sustainable waste and ability to remove the waste from the waste stream for an extended period. Hence, this investigation produced a new ideas to this research by using plastic to enhance and produce a sustainable and lightweight interlocking paving block. The purpose of this research is to assess the potential of plastic waste (LDPE) as a new alternative material to substitute cement content in a pavement block through evaluation of its compressive strength, water absorption, and weight performance. This evaluation was performed at different LDPE/sand blends, which were 1:1, 1:2, 1:3, and 1:4. This research was carried out to address two main problems, which were cement content in the production of concrete interlocking pavement block and plastic waste. Hence, a holistic study was performed to develop Eco-IPB from plastic wastes to build a green technology in the construction sector. This research's leading scope was limited to the following aspect as shown in Figure 1. 


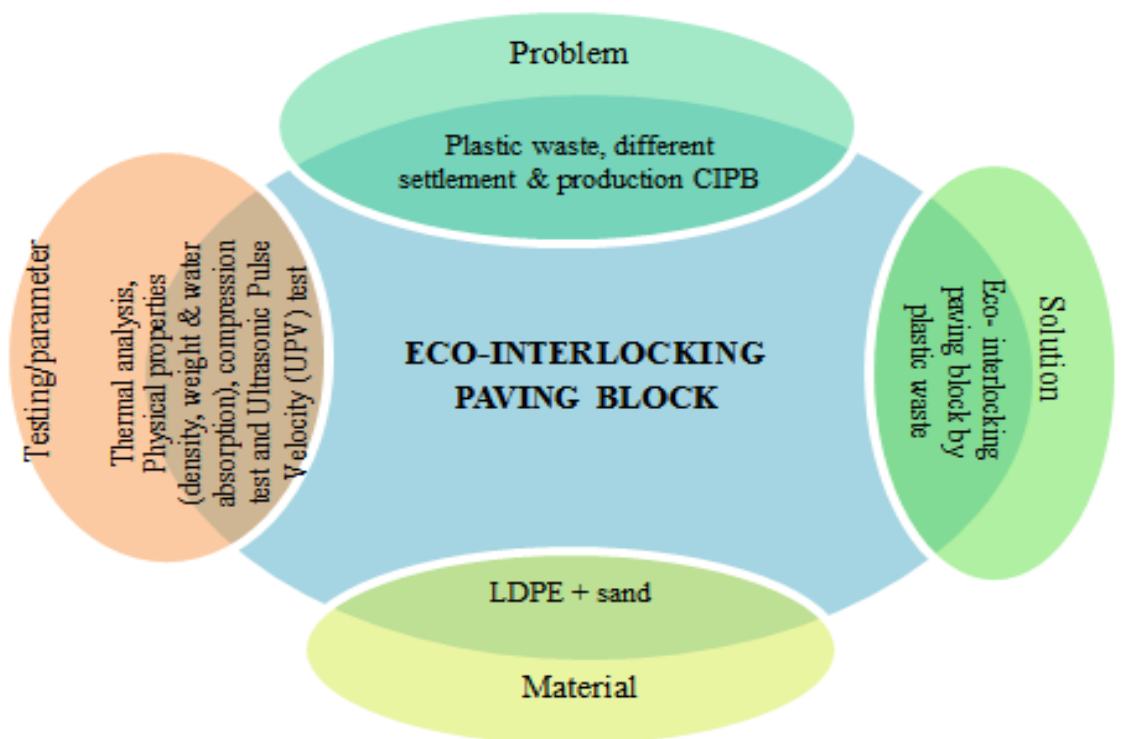

Fig. 1- Scope of the research

\section{Materials and Methods}

\subsection{Materials}

Two types of material mainly used in this research were LDPE and sand. Both materials were mixed to produce alternative interlocking paving block (known as Eco-IPB) for sustainable road construction.

\section{a) Low Density Polyethylene (LDPE)}

This research used LDPE as shown in Figure 2 to substitute the cement content in normal IPB production. Besides to overcome the environmental issues created by plastics, LDPE waste was also chosen as a new alternative material for Eco-IPB due to its excellent properties such as ductile, lightweight, durable, flexible and economical. LDPE is a thermoplastic made from oil. The density and specific gravity of LDPE are $0.912 \mathrm{~g} / \mathrm{cm}^{3}$ and 0.914 , respectively. The LDPE (plastic bag) used in this research was collected around Pagoh restaurant. A plastic bag was dried to remove the current inside the plastic and washed with normal water. Then, the plastic bag was cut into square size of $10 \mathrm{~cm} x 10$ $\mathrm{cm}$ to ensure a smooth process of batching and burning.

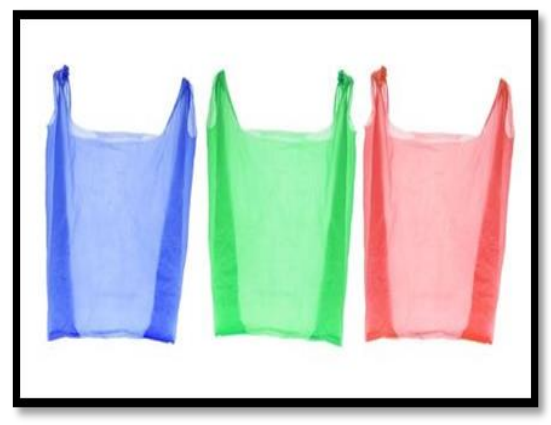

Fig. 2 - Plastic Bag (LDPE)

\section{b) Sand}

Sand is naturally occurring granular material is composed of mineral particles and finely material. Natural river sand was used as fine aggregate which passed through $4.25 \mathrm{~mm}$ sieve size as shown in Figure 3 . This sand has a specific gravity of 2.58 . 


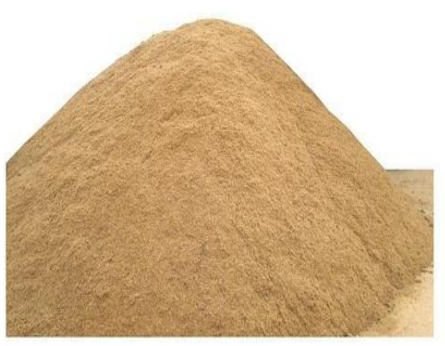

Fig. 3 - Sand

\section{c) Eco-Interlocking Paving Block (Eco-IPB)}

The Eco-IPB contains two main materials, namely LDPE (by plastic bag) and sand. Innovative use of LDPE plastic waste for interlocking paving block technology is one of the sustainable solutions, which reduces the total amount of plastic waste dump into landfill. In this research, the Eco-IPB was fabricated into size of $100 \mathrm{~mm}$ x $100 \mathrm{~mm}$ x $60 \mathrm{~mm}$ in order to suit with the base of the compression machine used. The Eco-IPBs were made using four different LDPE/sand blends of 1:1, 1:2, 1:3 and 1:4 as outlined in Table 2. The LDPE (plastic bags) and sand were mixed equally to $1400 \mathrm{~g}$ and $4200 \mathrm{~g}$ for one (1) block and three (3) blocks respectively, as outlined in Table 3 .

Table 2 - Different mix ratios of tested samples

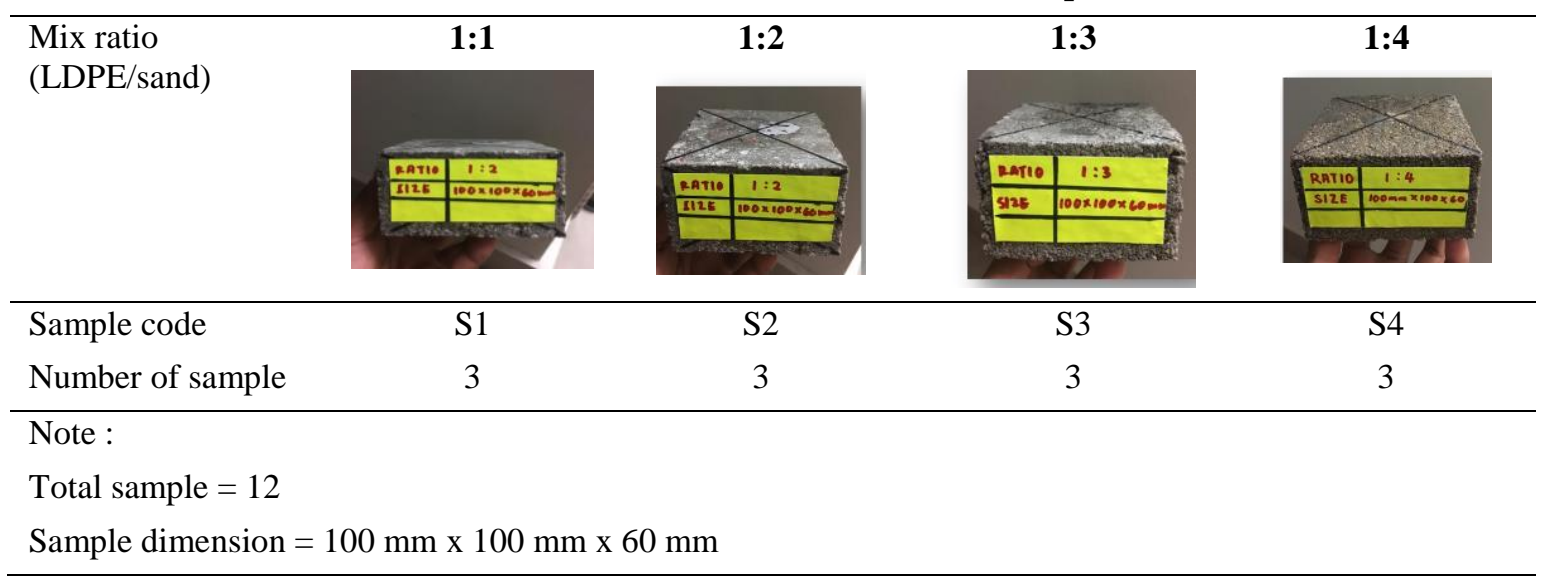

Table 3 - Mix design proportion of Eco-IPB

\begin{tabular}{ccccc}
\hline $\begin{array}{c}\text { Mix ratio } \\
\text { (LDPE/sand) }\end{array}$ & $\mathbf{1 : 1}$ & $\mathbf{1 : 2}$ & $\mathbf{1 : 3}$ & $\mathbf{1 : 4}$ \\
\cline { 2 - 5 } Sample code & $\mathrm{S} 1$ & $\mathrm{~S} 2$ & $\mathrm{~S} 3$ & $\mathrm{~S} 4$ \\
\hline For 1 paver $(\mathrm{g})$ & $700: 700$ & $467: 933$ & $350: 1050$ & $280: 1120$ \\
For 3 paver $(\mathrm{g})$ & $2100: 2100$ & $1401: 2799$ & $1050: 3150$ & $840: 3360$ \\
\hline
\end{tabular}

In the Eco-IPB casting process, the plastic bag was melted by burning it for 20 minutes. When the plastic bag completely melts, the sand was added and stirred for 10 minutes under fire. Make sure that the plastic's melt and sand are thoroughly mixed in order to avoid the Eco-IPB structure from cracking or honeycomb as well as to increase the bonding of the mixture of sand and plastic. The mixture was then poured into the timber mould with the internal dimension of $100 \mathrm{~mm}$ length, $100 \mathrm{~mm}$ wide and $60 \mathrm{~mm}$ thick in three equal layers. Each layer was manually compacted by 25 blows using a tamping rod. The samples were kept in the mould for 24 hours to allow it to be completely dried as recommended by Thirugnanasambantham, et al. [12]. However, the specimens were tested after 28 days.

\subsection{Methods}

Two series of laboratory tests were carried out on casted Eco-IPB (in the size of $100 \times 100 \times 6 \mathrm{~mm}$ ) to determine its physical and mechanical properties. The density and water absorption tests were evaluated as physical properties and mechanical properties of the sample were assessed via an axial compression test. 


\section{a) Density}

The density of samples was measured to evaluate the effect of the LDPE ratio on the IPB weight. It was therefore important to control the consistency of the samples to obtain reliable data. The density was calculated based on the Equation 1.

$$
\text { Density }=\frac{\text { Mass }(\mathrm{M})}{\text { Volume (V) }}
$$

\section{b) Water Absorption Test}

Water absorption test was carried out to evaluate the effects of Eco-IPB when exposed to water or humid condition on such properties. It was also functioned as a control test for the uniformity of a block. This test was conducted in accordance with the Malaysian Standard (MS76:1972).

Firstly, the test specimens were dried under sunlight until a constant weight is achieved. Then, the specimens were weighted to a precision of $0.001 \mathrm{~g}$ and noted as a dry specimen. Next, the specimens were immersed into a water tank and kept at room temperature. After $24 \mathrm{hrs,} \mathrm{the} \mathrm{specimens} \mathrm{were} \mathrm{removed} \mathrm{from} \mathrm{the} \mathrm{tank,} \mathrm{and} \mathrm{the} \mathrm{surface} \mathrm{water} \mathrm{was}$ wiped with a damp cloth. After 2 minutes being removed from the water, the specimens were weighed again and recorded as wet specimens. The percentage of water absorption (WA) was determined by the difference between the significantly saturated weight and dry weight, as expressed in Equation 2. Kasim and Rohim [1] reported that the lower the water absorbed by the interlocking block, the higher the quality.

$$
\text { Water absorption (WA), } \%=\frac{w 2-w 1}{w 1} x 100
$$

where,

$$
\begin{aligned}
& \mathrm{w} 1=\text { Weight of dry IPB }(\mathrm{kg}) \\
& \mathrm{w} 2=\text { Weight of wet IPB }(\mathrm{kg})
\end{aligned}
$$

\section{c) Axial Compression Test}

The axial compression test is one of the significant properties used to determine the efficiency of the material subjected to vertical loading. The tests were conducted on four different LDPE/sand blends of 1:1, 1:2, 1:3, and 1:4. Three samples for each blend were tested with the average value reported in this paper. All specimens were tested with a Semi Auto 3000kN Compression Machine as shown in Figure 4. The test specimens were placed in the machine by aligning with those at the top and base plate. Then, the specimens were loaded until failed. The compression test was performed in accordance with the procedure outlined in MS 1933: Part 1: 2007 compression test standards [2].

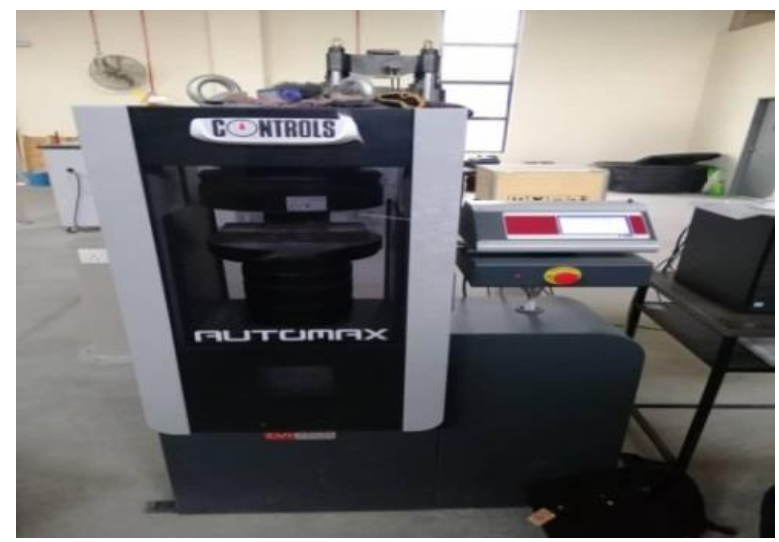

Fig. 4 - Compression Testing Machine

\section{Results and Discussions}

\subsection{Density of Eco-IPB}

Figure 5 shows the density of Eco-IPB at different percentage ratios. The results showed that the density of EcoIPB increase from 1483.33 to $1916.67 \mathrm{~kg} / \mathrm{cm}^{3}$ with increasing of sand content in the blends, parallel to the reduction of LDPE content. It is presumable because the plastic itself has a very low density of $0.912 \mathrm{~g} / \mathrm{cm}^{3}[13 ; 14]$ compared to the cement density of $1.44 \mathrm{~g} / \mathrm{cm}^{3}$. The correlation coefficient value in Figure 4 showed that the R2 value was closest to 1 which indicated a strong relationship between density and LDPE / sand blend, thereby providing a reliable predictive value. 


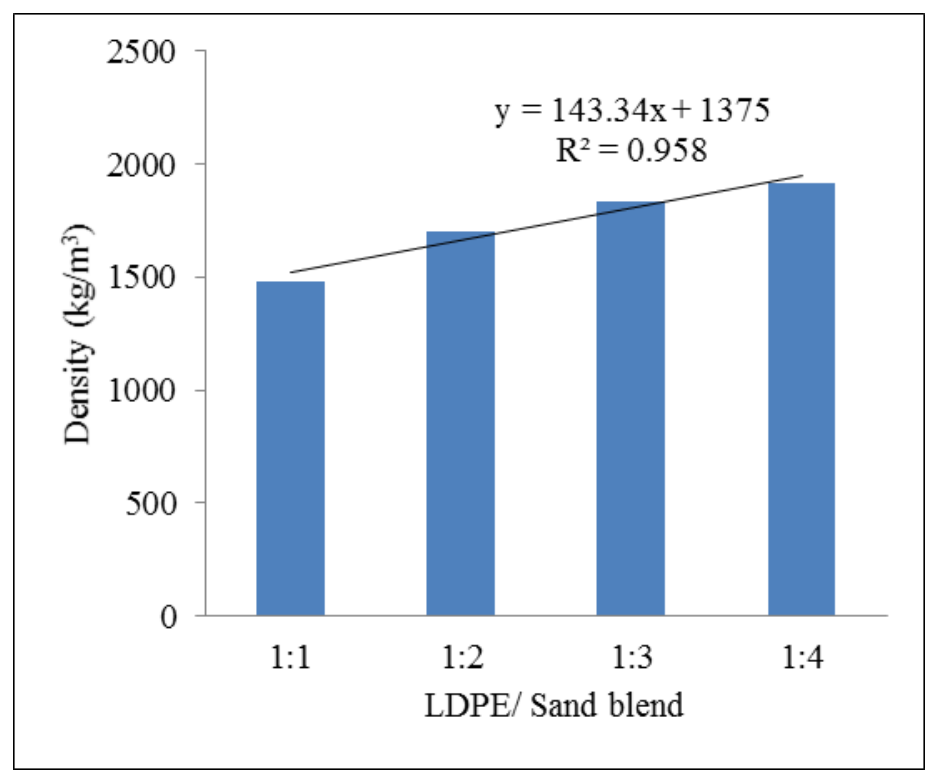

Fig. 5 - Density of Eco-IPB at Different LDPE/sand blends

\subsection{Water Absorption}

Water absorption was performed to determine the minimum and maximum allowable water absorption rates of Eco-IPB due to its product mainly used for outdoor purposes such as for pedestrian, landscape, parking, operation area and other relevant areas. This is because the production of interlocking blocks must be resilient to the changing weather elements in Malaysia, particularly those with frequent monsoon transitions. Figure 6 shows the percentage of water absorption (for $24 \mathrm{hrs}$ ) at different LDPE/sand blends. The results showed that the water absorption significantly increased with the decrease of LDPE content and increase of sand contents. This also indicated that the amount of sand had influenced the water absorption of the sample as the attribute of sand is high water absorption. A similar pattern also reported by Kasim and Rohim [1]. However, water absorption percentage for the entire paving block sample prepared using blend LDPE and plastic was much lower than the permissible value of $7 \%$ [14]. This is good for the practical implementation and reliability of the paving block as recommended by Natarja and Das [15]. The correlation coefficient value in Figure 5 showed that the data had a good relationship and was reliable for predictive analysis.

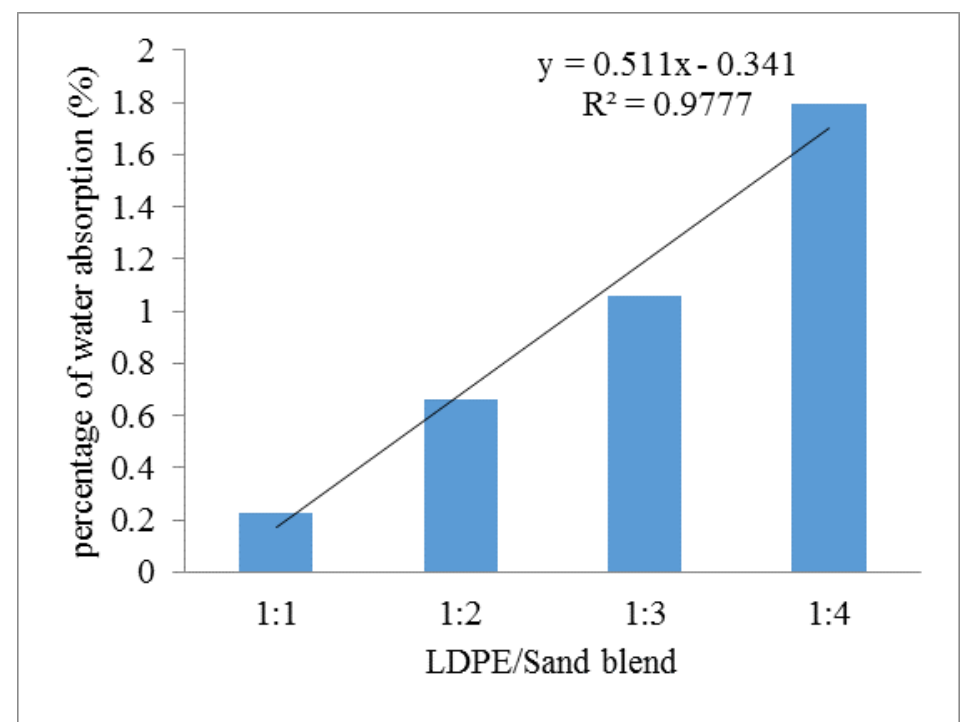

Fig. 6 - Water Absorption of Eco-IPB at different LDPE/Sand blends

\subsection{Compressive Strength}

Figure 7 shows the effect of LDPE/Sand blends on compressive strength. The results indicated that the maximum compressive strength was $20.09 \mathrm{MPa}$, achieved at 1:2 LDPE/sand blend; while the minimum compressive strength was 6.58 $\mathrm{MPa}$, discovered at 1:4 LDPE/sand blend. It means that compressive strength is diminished by increasing the sand 
in Eco-IPB, but if too much LDPE will also reduce compressive strength in Eco-IPB. The compressive strength values obtained for the paver block were not higher than the compressive strength required. This is because the production of Eco-IPB during moulding process without hydraulic press will affect the compressive strength of Eco-IPB. Nevertheless, this product can be used for low-duty applications such as landscaping.

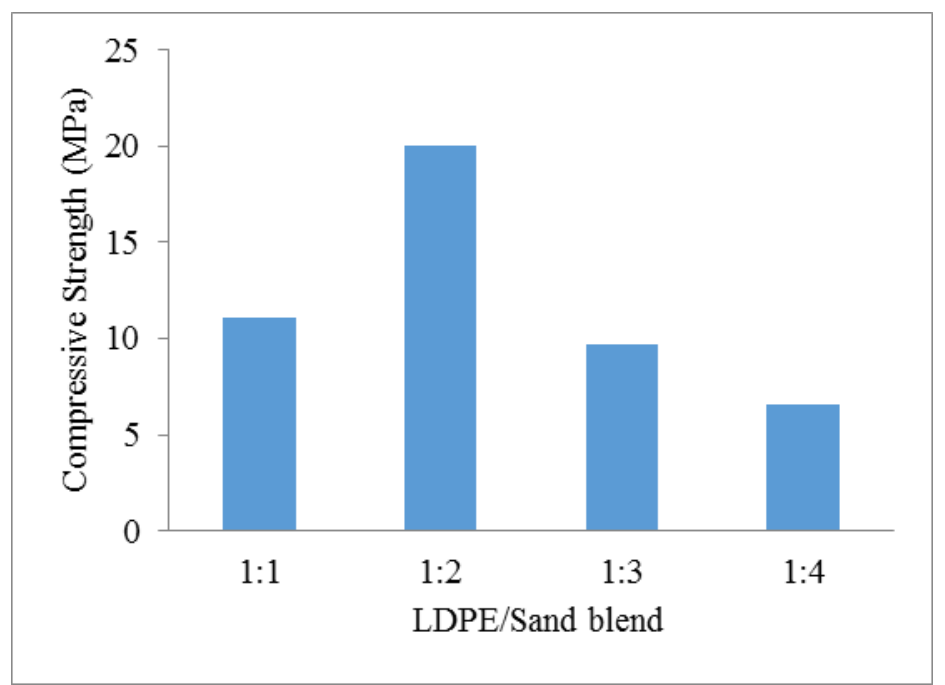

Fig. 7 - Compressive Strength of Eco-IPB with Blend (LDPE: Sand)

\section{Conclusions}

In this research, the effect of LDPE/Sand blend (1:1, 1:2, 1:3 and 1:4) on the density, water absorption and tensile strength of Eco-IPB were evaluated. The findings showed that density and water absorption increased when sand content increased and LDPE decreased. The optimum compressive strength of $20.09 \mathrm{MPa}$ was achieved with 1:2 LDPE/Sand blend, and it is suitable for landscaping purpose as recommended by Kasim and Rohim [1]. It was shown that the LDPE has the potential to replace cement contents in order to produce a sustainable, lightweight and economical product.

\section{Acknowledgement}

The authors would like to thank the Ministry of Education Malaysia for financial support under Fundamental Research Grant Scheme Vot. No. FRGS/1/2018/TK10/UTHM/03/3 and partially sponsored by Universiti Tun Hussein Onn Malaysia.

\section{References}

[1] Kassim, U. \& Rohim, O. M. (2017). Sustainable green interlocking pavement block. Journal of Advanced Research in Applied Sciences and Engineering Technology, Vol. 8 (1), 1-7.

[2] Patel, V. K. \& Singh, V. V. (2017). An Experimental Investigation on Precast Cement Concrete Paver Blocks using Fly Ash. International Journal of Advance Research, Ideas and Innovations in Technology, Vol. 3(6), 971 981.

[3] Tuffour, I. S. B. (2016). Development of Pavement Blocks Using Waste PET Bottles. Grin Verlag. Retrieved from https://www.grin.com/document/324198/

[4] Rollings, R. S. (1984). Corps of engineer's design method for concrete block pavements. In Proc., Second International Conference on Concrete Block Paving, Delft, 147-151.

[5] Stajanča, M., \& Eštoková, A. (2012). Environmental impacts of cement production. Civil Engineering Faculty, Institute of Architectural Engineering. Technical University of Košice.

[6] Ali, M. B., Saidur, R., \& Hossain, M. S. (2011). A review on emission analysis in cement industries. Renewable and Sustainable Energy Reviews, 15(5), 2252-2261.

[7] Infra Construction \& Equipment Magazine (2020). Interlocking Concrete Paver Blocks. NBM Media Pvt. Ltd. Retrieved on January, 2020, from https://www.nbmcw.com/tech-articles/concrete/4993-interlocking-concretepaver-blocks/

[8] SWCorp (2016). Survey on Solid Waste Composition, Characteristics \& Existing Practice of Solid Waste Recycling in Malaysia (2012). 
[9] Leblanc, R. (2018). The Decomposition of Waste in Landfills: A Story of Time and Materials. Sustainable Businesses. Retrieved from https://www.thebalancesmb.com/how-long-does-it-take-garbage-to-decompose2878033/

[10] Ten, M. (2018). Malaysia Ranks 8th among Nations that Mismanage Waste. Borneo Post. Retrieved from https://www.theborneopost.com/2018/04/28/malaysia-ranks-8th-among-nations-that-mismanage-waste/

[11] Abdullah, N. M. (2018). The Huge Problem of Plastic Waste in M'sia. Malaysiakini. Retrieved from https://www.malaysiakini.com/letters/428508/

[12] Thirugnanasambantham, N., Kumar, P. T., Sujithra, R., Selvaraman, R., Bharathi, P. (2017). Manufacturing and Testing of Plastic Sand Bricks. International Journal of Science and Engineering Research (IJ0SER), Vol. 5 (4), 150-155.

[13] Kormin, S., Kormin, F., Hossen Beg, M. D., \& Mat Piah, M. B. (2015). Study the physical, mechanical, thermal and morphological properties of LDPE/SAGO starch blend. ARPN Journal of Engineering and Applied Sciences, $1-8$.

[14] Ismail, T.N.H.T. (2017). A critical performance study on innovative lightweight fill to mitigate settlement of embankment constructed on peat soil. Universiti Tun Hussein Onn Malaysia: PhD Thesis.

[15] Nataraja, M. C., \& Das, L. (2006). A study on the strength properties of paver blocks made from unconventional materials. IOSR Journal of Mechanical and Civil Engineering (IOSR-JMCE), 1-5. 